\title{
TELAAH KRITIS ILMU KEPEMIMPINAN PERSPEKTIF KONSEP PARTIKEL DASAR PENYUSUN ATOM UNTUK MEMBENTUK KARAKTER PEMIMPIN HARAPAN
}

\author{
Mustofa \\ SMA Negeri 3 Kota Mojokerto \\ mustofa7419@gmail.com
}

\begin{abstract}
The education sector or school for the Indonesian nation is a strategic industry of civilization to form a generation with character in the future. Nowadays, it has very tough challenges in the form of a character crisis, human resources and a leadership crisis. The urgent problem that will be described in the discussion of this article is how leadership science at the atomic level is the perspective of learning the basic atomic particles, what is the importance of the results of the analysis of leadership science at the atomic level for the development of character education in schools and how efforts should be made to make the education sector or schools as factories for Indonesian human civilization in the future. The science of leadership at the atomic level that can be developed in the study of the basic particles that make up atoms requires, among others, that the leader has competence, integrity, wisdom and commitment. The results of the analysis of leadership science at the atomic level in the perspective of learning the basic particles of atomic constituents are very important to provide meaningful experience about the character of storage in the future. Efforts that must be made to make the education sector or schools as factories for Indonesian human trafficking in the future are to encourage awareness from all parties to work together in a real, honest and oriented manner towards enhancing the character and development of superior Indonesian human resources.

Keywords: leadership, elementary particles of atoms, character.
\end{abstract}

\begin{abstract}
Abstrak: Sektor pendidikan atau sekolah bagi bangsa Indonesia adalah industri strategis peradaban untuk membentuk generasi berkarakter di masa depan saat ini memiliki tantangan yang sangat berat berupa krisis karakter, SDM dan krisis kepemimpinan. Masalah urgen yang akan diuraikan pada pembahasan artikel ini adalah bagaimana ilmu kepemimpinan pada level atomik perspektif pembelajaran patikel dasar penyusun atom, apa pentingnya hasil analisis tentang ilmu kepemimpinan pada level atomik bagi pengembangan pendidikan karakter di sekolah dan bagaimana usaha yang harus dilakukan untuk menjadikan sektor pendidikan atau sekolah sebagai pabrik-pabrik peradapan manusia Indonesia di masa yang akan datang. Ilmu kepemimpinan pada level atomik yang dapat dikembangkan dalam pembelajaran partikel dasar penyusun atom antara lain mensyaratkan agar pemimpin itu memiliki kompetensi, integritas, bijaksana dan komitmen. Hasil analisis tentang ilmu kepemimpinan pada level atomik perspektif pembelajaran patikel dasar penyusun atom sangat penting untuk memberi pengalamam bermakna tentang karakter pemimpan di masa yang akan datang. Usaha yang harus dilakukan untuk menjadikan sektor pendidikan atau sekolah sebagai pabrik-pabrik peradapan manusia Indonesia di masa yang akan datang adalah mendorong kesadaran dari semua pihak untuk bersama-sama bekerja secara nyata, jujur dan berorientasi pada peningkatan karakter dan pengembangan sumber daya manusia Indonesia yang unggul.
\end{abstract}

Kata kunci: kepemimpinan, partikel dasar penyusun atom, karakter. 


\section{Pendahuluan}

Peraturan Menteri Pendidikan dan Kebudayaan Republik Indonesia Nomor 64 Tahun 2013 tentang Standar Isi Pendidikan Dasar dan Menengah menjelaskan bahwa dalam setiap mata pelajaran memiliki rumusan kompetensi sikap spiritual dan kompetensi sikap sosial yang menjadi standar output bagi peserta didik setelah menempuh proses pendidikan dan juga menjadi dasar bagi guru untuk mengembangkan karakter peserta didik melalui mata pelajaran yang diampunya. Standar Isi ini merupakan penjabaran secara detail dari amanat Undang-undang Pendidikan Nomor 20 Tahun 2003 tentang Sistem Pendidikan Nasional yang intinya adalah semua proses pendidikan tidak hanya berorientasi kepada pencapaian kompetensi pengetahuan dan keterampilan saja, tetapi juga harus berorientasi kepada pencapaian kompentesi sikap spiritual dan kompetensi sikap sosial atau menjadikan peserta didik sebagai manusia Indonesia yang memiliki ilmu, keterampilan, kekuatan spiritual dan kepekaan sosial.

Uraian di atas menjadi landasan yang kuat bagi bangsa Indonesia untuk menjadikan sektor pendidikan atau sekolah sebagai pabrik-pabrik peradapan manusia Indonesia yang akan menjadikan manusia Indonesia mampu menjawab tantangan pendidikan abad 21 serta harus mampu mewujud lahirnya generasi emas Indonesia di tahun 2045. Oleh karena itu alokasi dana untuk sektor pendidikan sebesar 20\% dari APBN atau sebesar Rp. 492,5 T pada tahun 2019 dinaikkan menjadi Rp. 505,8 T pada tahun 2020 harus benar-benar dapat direalisasikan dan dapat dibelanjakan dengan tepat dan diawasi penggunaannya secara ketat.

Upaya saat ini untuk menjadikan sektor pendidikan atau sekolah sebagai pabrik-pabrik peradapan manusia Indonesia sangat sulit diwujudkan. Menurut Menteri Pendidikan, Muhadjir pada tahun 2019 sektor pendidikan masih belum mampu menuntaskan pekerjaan rumah tentang masalah akses pendidikan, krisis karakter, pesatnya perkembangan teknologi, perubahan demografi, rendahnya indeks literasi pengetahuan, budaya, integrasi internet dan informasi serta tingginya angka pengangguran (Gatra.com:2019). Keadaan ini semakin parah dengan munculnya wabah virus corona yang mulai teridentifikasi positif di Indonesia pada bulan maret 2020, akibatnya kegiatan tatap muka harus diganti dengan belajar dari rumah yang secara psikologis baik guru, peserta didik dan orang tua belum tentu siap menghadapi kondisi ini (Antaranews.com:2020).

Faktor lain yang juga berkontribusi besar sebagai penghalang terwujudnya sektor pendidikan atau sekolah sebagai pabrik-pabrik peradapan manusia Indonesia di masa yang akan datang adalah krisis kepemimpinan di Indonesia, saat ini sangat sulit menemukan seorang pemimpin yang berkepribadian kuat, dengan kecerdasan di atas rata-rata dan memiliki keteladanan dalam segala aspek kehidupan. Ada kecenderungan kepemimpinan saat ini hanya berorientasi pada dominasi kekuasaan atas kelompok atau individu dan minim keteladanan (Raditya:2015)

Keadaan kontekstual di Indonesia yang tidak kondusif untuk menjadikan sektor pendidikan atau sekolah sebagai pabrik-pabrik peradapan manusia Indonesia akan berimbas pada beratnya beban guru dalam memegang peran sebagai kreator pendidikan. Guru saat ini dituntut untuk memiliki kreativitas yang tinggi dan tetap berkontribusi besar ditengah-tengah krisis multi dimensi demi memberi bekal pengalaman yang berharga bagi generasi yang akan datang. Guru harus mampu melahirkan kembali pemimpin yang kuat untuk memperjuangkan kepentingan rakyatnya, menjaga wilayah dan kedaulatan 
negaranya serta berwawasan global (Siswanto:2013)

Oleh karena itu upaya strategis guru untuk menjadi teladan sekaligus kreator penumbuhan karakter bagi peserta didiknya melalui aktivitas pembelajaran di kelas harus terus diapresiasi dan diberi kesempatan secara luas sehingga dapat memainkan peran ganda untuk perubahan dirinya sendiri juga untuk menciptakan perubahan bagi peserta didik menuju Indonesia Emas 2045. Salah satu upaya kreatif guru untuk menganalisis atau menelaah secara kritis konsep partikel dasar penyusun atom yang harus dipelajari oleh peserta didik kelas $\mathrm{X}$ program MIPA jenjang SMA dan kaitannya dengan seni memimpin atau teori kepemimpinan dapat dijadikan pengalaman berharga dan strategis bagi peserta didik untuk melihat secara ilmiah miniatur struktur kepemimpinan pada level atomik atau secara mikroskopis.

Masalah urgen yang akan diuraikan pada pembahasan artikel ini antara lain mengungkap tentang:

1. Bagaimana seni ilmu memimpin atau teori kepemimpinan pada level atomik atau secara mikroskopik perspektif pembelajaran patikel dasar penyusun atom yang dipelajari peserta didik kelas X program MIPA jenjang SMA?

2. Apa pentingnya hasil analisis tentang seni memimpin atau teori kepemimpinan pada level atomik atau secara mikroskopik perspektif pembelajaran patikel dasar penyusun atom yang dipelajari peserta didik kelas X program MIPA jenjang SMA bagi pengembangan pendidikan karakter di sekolah?

3. Bagaimana usaha yang harus dilakukan untuk menjadikan sektor pendidikan atau sekolah sebagai pabrik-pabrik peradapan manusia Indonesia di masa yang akan datang?

\section{Ilmu Kepemimpinan}

Menurut hasil investigasi secara spekulatif Leucippus yang menyebutkan bahwa atom adalah partikel penyusun materi terkecil yang tidak dapat dipisahkan, pernyataan ini dibuktikan secara eksperimen oleh Daltaon melalui hukum kekekalan masa pada tahun 1803 hingga 1807. Pada tahun 1897 J. J. Thomson memperkenalkan hasil eksperimennya yaitu atom berupa bola pejal bermuatan positif yang di dalamnya tersebar merata elektron. Penemuan ini selanjutnya dibantah oleh Rutherford berkat hasil eksperimennya melalui penembakan plat emas dengan sinar- $\alpha$ pada tahun 1902, ternyata menemukan bahwa inti atom bermuatan positif, kemudian bagaimana elektron bergerak mengelilingi inti dijelaskan oleh Niels Bohr. Pada tahun 1932 Chadwick menambahkan bahwa di dalam inti atom juga terdapat neutron, yaitu suatu partikel yang tidak bermuatan. Teori atom semakin sempurna setelah Schrodinger berhasil menemukan konsep orbital yaitu probabilitas terbesar untuk menemukan elektron di sekitar inti melalui persamaan Schrodinger.

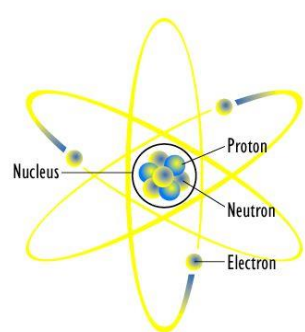

Gambar 1. Model Atom Niels Bohr (Sumber: https://www.khanacademy.org diakses 17 Oktober 2020)

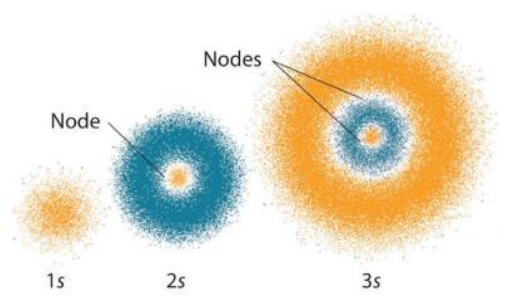

Gambar 2. Orbital dalam Teori Atom Modern (Sumber: https://www.khanacademy.org diakses 17 Oktober 2020) 


\section{a. Memiliki Kompetensi}

Uraian tentang bagaimana partikel dasar penyusun atom seperti proton, elektron dan neutron diletakkan dalam sebuah atom berdasarkan hasil penelitihan para ilmuwan dapat disimpulkan bahwa proton yang bermuatan positif dan neutron yang merupakan partikel netral atau tidak bermuatan akan menempati inti, sedangkan elektron yang bermuatan negatif menempati orbital disekitar inti. Fakta ini menunjukkan bahwa pada level atomik atau mikroskopik yang boleh menempati inti adalah proton atau partikel yang bermuatan positif, sehingga analogi pada konteks level makronya adalah yang boleh menduduki pengurus atau jabatan inti atau penting dalam sistem organisasi apapun harus berisi orang-orang yang baik atau yang terbaik di bidangnya.

Nabi Muhammad SAW telah memprediksi melalui sebuah hadis yang diriwayatkan oleh Imam Bukhari pada hadis nomor 6015 menyatakan dengan tegas bahwa siapa pun akan mendapati kehancuran jika amanat itu diberikan kepada pemangku amanat yang tidak tepat atau bukan ahli untuk menerima amat tersebut. Pada hadis yang lain yang diriwayatkan oleh Imam Abu Dawud, Nabi Muhammad SAW juga secara tegas menyatakan bahwa jika Allah menghendaki kebaikan pada suatu kaum atau bangsa maka Allah akan mengangkat orang-orang yang cakap dan bijak untuk menjadi pemimpin. Sebaliknya jika Allah menghendaki keburukan bagi suatu kaum atau bangsa, maka Allah akan menjadikan orang yang bodoh sebagai pemimpin.

\section{b. Memiliki Integritas}

Inti atom di samping berisi proton juga berisi neutron atau partikel yang tidak bermuatan. Partikel neutron dalam inti atom memiliki fungsi strategis untuk menyeimbangkan gaya tolak antar proton yang terjadi di dalam ini sehingga inti atom tetap stabil. Pada level makro fakta ini memberi pelajaran tentang karakter kepemimpinan bahwa siapa pun orangnya jika sudah terpilih menjadi pimpinan atau menempati posisi puncak pada suatu lembaga atau organisasi, maka dia harus fokus pada amanat yang diberikan dan netral atau menjaga diri dari menyalahgunakan kekuasaan atau wewenang untuk kepentingan pribadi atau golongannya.

Nabi Muhammad SAW secara tegas menyatakan dalam sebuah hadis yang diriwayatkan oleh Imam Bukhari hadis nomor 6788 dan riwayat Imam Muslim hadis nomor 1688 yang isinya adalah kebinasaan orang-orang terdahulu karena jika yang mencuri orang kaya dibiarkan atau tidak dihukum dan jika yang mencuri orang lemah akan dihukum. Bahkan Nabi menegaskan seandainya yang mencuri Fatimah binti Muhammad maka aku sendiri yang akan memotong tangannya.

\section{c. Bijaksana}

Elektron atau partikel yang bermuatan negatif akan selalu bergerak mengelilingi inti sesuai dengan tingkat energi atau orbital yang ditempatinya. Jika elektron diidentikan dengan karakter negatif, maka inti akan menjadi berubah menjadi kation atau atom-atom yang bermuatan positif jika atom melepaskan elektronnya. Sebaliknya akan menjadi anion atau atom-atom yang bermuatan negatif jika menangkap elektron. Pada level makro pendidikan karakter yang dapat dimunculkan adalah kebijakan yang dikeluarkan oleh seorang pemimpin pro rakyat atau tidak dapat diprediksi dari siapa pembisiknya.

Nabi Muhammad SAW pernah mengingatkan melalui hadis yang diriwayatkan oleh Imam Bukhari hadis nomor 5534 dan hadis yang diriwayatkan Imam Muslim hadis nomor 2628 yang menyatakan bahwa permisalan teman 
yang baik dengan teman yang buruk seperti penjual minyak wangi dan tukang pande besi, artinya jika ingin bau harum, harus berteman dengan penjual minyak wangi sebaliknya akan mendapati bau tak sedap jika berteman dengan tukang pande besi.

\section{d. Memiliki Komitmen}

Inti atom akan stabil atau tidak mudah mengalami peluruhan atau reaksi inti jika memiliki perbandingan jumlah proton dan neutron sama dengan satu dan nomor atomnya tidak melebihi 83. Hal ini memiliki kosekuensi jika inti memiliki perbandingan jumlah proton dan neutron tidak sama dengan satu atau nomor atomnya melebihi 83, maka inti itu akan mengalami peluruhan atau reaksi inti hingga mendapati inti yang stabil. Fakta ini memberi pelajaran penting bahwa proses untuk menjadi pemimpin yang kompeten dan memiliki integritas itu tidak mudah tetapi harus melalui tahapantahapan seleksi yang ketat atau fit and proper test untuk menguji kompetensi dan integritas.

\section{Tantangan Pengembangan Karakter di Sekolah}

Anis Matta menyatakan bahwa Indonesia saat ini tidak menuju ke arah yang benar, hal ini terbukti ketika pemerintah bersemangat membangun infrastruktur, rakyat merasa kehidupan makin berat dan rasa cemas akan masa depan makin meningkat (Tribunnews. com:2018). Keadaan ini sudah diprediksi oleh almarhum Prof. B.J. Habibie 9 tahun yang lalu tentang mengemukanya fenomena paradok-sial tentang Indonesia yaitu SDA alamnya melimpah tetapi minim penghasilannya, besar wilayahnya tetapi tidak produktif, mudah berbuat anarkis tetapi tidak berdaya pada tantangan global dan indah secara potensi tetapi buruk dalam pengolahannya, yang dalam perkembangannya fenomena ini disebut sebagai penyakit orientasi.
Wabah Covid-19 sudah hampir 8 bulan dan tetap menjadi ancaman yang mematikan di Indonesia, hal ini disebabkan karena Indonesia belum mampu mengatasi wabah secara menyeluruh bahkan himbauan pemerintah, pemimpin dan para ahli melalui berbagai media pun tidak mempan untuk mendedikasikan perilaku yang benar dalam berhadapan dengan Covid-19, ini merupakan indikasi bahwa SDM Indonesia masih belum mampu membentuk perilaku yang unggul.

Uraian di atas menggambarkan tantangan berat bagi pengembangan pendidikan karakter di sekolah, dan sekaligus menjadi informasi yang merugikan dalam pelaksanaan pendidikan karakter bagi peserta didik di masa yang akan datang, karena:

(1) lingkungan yang tidak sehat atau sakit orientasi, sangat memungkinkan untuk menjadi media penularan yang sangat efektif penyakit orientasi kepada peserta didik.

(2) ada kecenderungan bagi peserta didik dengan menghalalkan segala cara, untuk mencapai tujuan praktis yang diinginkannya secara instan.

(3) munculnya berperilaku menyimpang di kalangan peserta didik seperti perkelaian antar pelajar, pelecehan seksual, dan kenakalan remaja lainnya lebih mudah untuk terjadi.

Beban berat yang harus dihadapi sekolah untuk membentuk karakter peserta didik jika tidak segera di selesaikan hanya akan melahirkan peserta didik atau generasi yang tidak memiliki kompetensi spritual dan kompetensi sosial sesuai yang diharapkan seperti tertuang dalam standar isi kurikulum 2013.

\section{Revitalisasi Pendidikan Karakter di Sekolah}

Upaya konkret untuk menjadikan sekolah sebagai lembaga atau institusi yang efektif untuk membentuk generasi emas 2045 mutlak butuh kesadaran dari 
semua pihak untuk bersama-sama bekerja secara nyata, jujur dan berorientasi pada peningkatan SDM.

Langkah-langkah penting yang mungkin bisa dilakukan adalah:

(1) Pengawasan secara ketat dan berlapis terhadap penyelenggaran pendidikan dan kurikulum 2013 untuk menjamin bahwa pendidikan karakter betulbetul sudah dilaksanakan dengan benar.

(2) Ada apresiasi nyata bagi guru yang dapat menjadi teladan bagi pengembangan karakter peserta didik, juga ada panismen yang konkret bagi guru yang merusak pembentukan karakter peserta didik.

(3) Kepemimpinan di sekolah harus mendapat prioritas evaluasi dan pendampingan. Hal ini penting karena warga sekolah akan berkarakter jika kepemimpinan di sekolah juga berkarakter.

(4) Anggaran pendidikan harus dikontrol agar tepat sasaran dan tepat guna dan memfasilitasi pelaksanaan pendidikan karakter di sekolah.

(5) Konten kurikulum juga harus terus disempurnakan guna mendukung pelaksanaan pendidikan karakter di sekolah.

\section{Simpulan}

Kesimpulan yang diperoleh berdasarkan hasil penjabaran materi adalah sebagai berikut:

1. Ilmu kepemimpinan pada level atomik yang dapat dikembangkan dalam pembelajaran partikel dasar penyusun atom antara lain mensyaratkan agar pemimpin itu memiliki kompetensi, integritas, bijaksana dan komitmen.

2. Hasil analisis tentang seni memimpin atau teori kepemimpinan pada level atomik atau secara mikroskopik perspektif pembelajaran patikel dasar penyusun atom sangat penting untuk memberi pengalamam bermakna tentang karakter pemimpan di masa yang akan datang.

3. Usaha yang harus dilakukan untuk menjadikan sektor pendidikan atau sekolah sebagai pabrik-pabrik peradapan manusia Indonesia di masa yang akan datang adalah mendorong kesadaran dari semua pihak untuk bersama-sama bekerja secara nyata, jujur dan berorientasi pada peningkatan SDM.

\section{Daftar Pustaka}

Antaranews.com. 16 Maret (2020). Belajar dari Rumah, Kewalahan Orang Tua, hingga Kesiapan Guru. Diakses tanggal 15 Oktober 2020 pukul 19.25 WIB dari https://www.antaranews.com/berita /1363634/belajar-dari-rumahkewalahan-orang-tua-hinggakesiapan-guru

Dongoran, F.R. (2014). Paradigma Membangun Generasi Emas 2045 Dalam Perspektif Filsafat Pendidikan. Jurnal Tabularasa PPS UNIMED. Vol. 11, No. 1. Diakses tanggal 17 Oktober 2020 pukul 19.25 WIB dari https://jurnal.unimed.ac.id/2012/ind ex.php/tabularasa/article/view/3336

Ensiklopedi Hadis Kitab 9 Imam. Diakses tanggal 16 Oktober 2020 pukul 16.00 WIB dari https://hadits.in/bukhari/6015

Flowers, P., Theopold, K., Langley, R., et al. (2019). Evolution of Atomic Theory. Diakses tanggal 15 Oktober 2020 pukul 18.00 WIB dari https://chem.libretexts.org/Courses/ Oregon_Institute_of_Technology/O IT\%3A_CHE_101_-

_Introduction_to_General_Chemist ry/02\%3A_Atoms_and_the_Periodi c_Table/2.01\%3A_Evolution_of_At omic_Theory.

Gatra.com. 13 September (2019). Mendikbud Sebut 8 Tantangan 
Pendidikan Indonesia. Diakses tanggal 16 Oktober 2020 pukul 19.25 WIB dari https://www.gatra.com/detail/news/ 444158/milenial/mendikbud-sebut8-tantangan-pendidikanindonesia\#: : :text=Diungkapkan\%2 OMendikbud\%2C\%20delapan\%20t antangan\%20pendidikan,Rendah\% 2C\%20dan\%20Jumlah\%20Pengan gguran\%20yangners/2018/03/15/kr isis-kepemimpinan-dan-kebutuhanarah-baru-indonesia

Jayani, D.H. (2019). 2020, Anggaran Pendidikan Hanya Naik 2,7\%. Diakses tanggal 15 Oktober 2020 pukul 19.05 WIB dari https://databoks.katadata.co.id/data publish/2019/08/16/2020-

anggaran-pendidikan-hanya-naik-

27\#: :text $=$ Pidato $\% 20$ Presiden $\% 2$ ORepublik\%20Indonesia\%20menge nai,sebesar\%20Rp\%20492\%2C5\% 20triliun

Kementrian Keuangan Republik Indonesia. (2019). Anggaran Pendidikan APBN 2019, Mengetahui Sasaran Target dari Anggaran Pendidikan APBN 2019. Diakses tanggal 16 Oktober 2020 pukul $19.00 \quad$ WIB dari http://visual.kemenkeu.go.id/anggar an-pendidikan-apbn-2019/

Khan Academi. Bohr's Model of Hydrogen. Diakses tanggal 17 Oktober 2020 pukul 19.10 WIB dari https://www.khanacademy.org/scien celap-chemistry/electronicstructure-of-atoms-ap/bohr-modelhydrogen-ap/a/bohrs-model-ofhydrogen

Khan Academi. The Quantum Mechanical Model of The Atom. Diakses tanggal 15 Oktober 2020 pukul 19.15 WIB dari https://www.khanacademy.org/scien ce/physics/quantumphysics/quantum-numbers-and- orbitals/althe-quantum-mechanicalmodel-of-the-atom

Koesoema, Doni. (2007). Pendidikan Karakter, Strategi Mendidik Anak di Zaman Global. Jakarta: PT Gramedia Widiasarana Indonesia.

Tribunnews.com. 15 Maret (2015). Krisis Kepemimpinan dan Kebutuhan Arah Baru Indonesia. Diakses tanggal 16 Oktober 2020 pukul 19.05 WIB dari https://www.tribunnews.com/tribun ners $/ 2018 / 03 / 15 /$ krisis-

kepemimpinan-dan-kebutuhanarah-baru-indonesia.

Peraturan Menteri Pendidikan dan Kebudayaan Republik Indonesia nomor 64 Tahun 2013 tentang Standar Isi Pendidikan Dasar dan Menengah.

Raditya. Michael (2015). Kontestasi Kekuasaan dan Keteladanan Semu di Indonesia. Jurnal Ilmu Sosial dan Ilmu Politik, Vol. 19, No.1 hal. 116.

Siswanto. (2013). Sosok Presiden Ideal dan Tantangan Isu-isu Global: Menimbang Aspek Kepemimpinan Capres Pada Pilpres 2014. Jurnal Penelitian Politik, Vol. 10, hal. 113.

Undang-undang Pendidikan Nomor 20 Tahun 2003 tentang Sistem Pendidikan Nasional. 